Journal of Clinical Investigation

Vol. 41, No. 11, 1962

\title{
ISOZYMES OF LACTIC DEHYDROGENASE; THEIR ALTERATIONS IN ARTHRITIC SYNOVIAL FLUID AND SERA *
}

\author{
By ELLIOT S. VESELL, KIRK C. OSTERLAND, $†$ ALEXANDER G. BEARN, AND \\ HENRY G. KUNKEL \\ (From the Rockefeller Institute, New York, N. Y.)
}

(Submitted for publication May 17, 1962; accepted July 26, 1962)

In 1950 Meister (1) first described the electrophoretic heterogeneity of crystallized beef heart lactic dehydrogenase (LDH); in 1952 Neilands (2) confirmed this observation and demonstrated that each of the two LDH enzymes obtained was enzymatically active. In 1957 the heterogeneity of lactic dehydrogenase activity in normal human serum was initially described (3). One peak of serum LDH activity was observed to become selectively elevated in myocardial infarction (3); a second peak was differentially increased in leukemic sera (3). Subsequently additional peaks of serum LDH activity were found to be raised early in the course of hepatitis (4). Multiple molecular forms of other enzymes such as malic dehydrogenase were demonstrated in normal human serum, and individual peaks of these were altered in various disease states (5). Enzymatic heterogeneity gained additional significance with the definition of an isozyme by Markert and M $\phi$ ller, who introduced the term to refer to multiple enzymes exhibiting similar substrate specificities (6). They clearly distinguished isozymes from different enzymes with overlapping but distinct substrate specificities (6). Electrophoretic separation of homogenates of various mammalian tissues showed that each tissue contained several $\mathrm{LDH}$ isozymes. Differences among tissues, either in the number or mobility of these isozymes, were reported (3-10). If each human tissue possessed a unique isozyme pattern, the possibility arose that diagnosis might be facilitated by electrophoretic separation of serum. This suggestion was based on the assumptions that the disorders to be differentiated affected organs whose isozyme patterns could be clearly distinguished from one another and that the tissue isozymes were released

* These studies were supported in part by grant-inaid A-k542 (C4) from the U. S. Public Health Service. $\dagger$ Fellow of Canadian Arthritis and Rheumatism Society. into the blood by the pathologic process. Although some human tissues such as heart and liver contain the majority of their $\mathrm{LDH}$ activity in two distinct isozymes, in the present report it will be shown that most human tissues have in common five $\mathrm{LDH}$ isozymes, the five isozymes in one tissue exhibiting similar electrophoretic mobilities to those observed in other tissues. Differences among human tissues have been emphasized previously (3-10), but these are largely differences in distribution of total LDH activity among the five isozymes.

The present study is concerned primarily with isozyme 5, the slowest migrating $\mathrm{LDH}$ isozyme, as it appears in normal synovium and in synovial fluid and sera from patients with rheumatoid arthritis. The results show that the $\mathrm{LDH}$ activity of arthritic synovial fluid is considerably higher than that of an equal volume of normal serum and that serum isozyme 5 was elevated in some arthritic patients. Previously it was recommended that isozyme 5 of serum, designated the "liver" isozyme because of its prominence in liver and because of its elevation early in the course of hepatitis, be used as an index of liver necrosis (11). It appears, therefore, that the degree of specificity to be expected from the application of serum isozymes to diagnostic problems merits closer examination.

Unfortunately, the nomenclature of isozymes has become confusing because American authors refer to the most rapidly migrating isozyme as isozyme $5(11,12)$, whereas European authors designate it isozyme $1(7,8,10)$. Since the European system conforms to the classical nomenclature of Tiselius, it seems best to adopt it in the interest of achieving uniformity, although either system if generally adhered to would be satisfactory. Further confusion results from the successful isolation of isozymes by chromatographic techniques $(8,13)$, where convention favors the opposite 
numbering system to that employed in classical electrophoresis.

\section{MATERIALS AND METHODS}

Four $\mathrm{ml}$ of serum was taken from each of 12 patients with joint effusions attributable to the conditions listed in Table I. Four $\mathrm{ml}$ of joint fluid was drawn aseptically from the knee joint of these 12 patients and two additional ones. Synovium was obtained at autopsy from two young healthy males within 6 hours of their death from vehicular accidents, as was human heart, kidney, liver, lung, muscle, and skin from five additional cadavers.

After thorough washing in cold normal saline, $2 \mathrm{~g}$ of each human tissue was rinsed in cold water to remove erythrocytes, and then diced and ruptured by sonic oscillation in $0.01 \mathrm{M}$ phosphate-citric acid buffer, $\mathrm{pH} 7.0$, for the heart, kidney, liver, lung, muscle, and skin and in $0.05 \mathrm{M}$ barbital buffer, $\mathrm{pH} 8.6$, for the synovium. Sonic disruption was performed at $4^{\circ} \mathrm{C}$ with a sonifier obtained from Heat Systems Company whose probe measured $8 \times 9 \mathrm{~mm}$. Application of 6 to 7 amperes for approximately 30 seconds was sufficient to reduce the diced tissues to a fine suspension. In several experiments human white cells prepared with the use of dextran from $40 \mathrm{ml}$ of whole heparinized blood (7) were disrupted by sonic oscillation instead of by repeated freezing and thawing (7).

After sonication the suspension was centrifuged for 90 minutes at $4^{\circ} \mathrm{C}$ in a Lourdes ultracentrifuge at 15,000 $\mathrm{G}$; the resulting clear supernatant fluid was decanted and separated electrophoretically. Four $\mathrm{ml}$ of each sample of sera, joint fluid, and synovium was separated on a starch-supporting medium in barbital buffer, $\mathrm{pH}$ 8.6, with an ionic strength of 0.05 , as described previously (14). Electrophoresis was carried out at $4^{\circ} \mathrm{C}$ for approximately 24 hours at about $400 \mathrm{v}$ and $80 \mathrm{ma}$. The sections of the block were cut into 0.5 inch segments: the protein was eluted from each segment with $4 \mathrm{ml}$ barbital buffer, $\mathrm{pH} 8.6$, ionic strength 0.05 , and its concentration determined (14). A sample from each eluate was then assayed spectrophotometrically for LDH activity (15). Between 90 and 100 per cent of the LDH activity of the starting material was recovered from the block after electrophoresis. Each eluate was incubated for 20 minutes at room temperature with $0.2 \mathrm{ml}$ of $0.003 \mathrm{M}$ diphosphopyridine nucleotide reduced (DPNH) and $2.5 \mathrm{ml}$ of barbital buffer, $\mathrm{pH} 8.6$, ionic strength 0.05 . The mixture was transferred to a Beckman cuvet of $1 \mathrm{~cm}$ path length; 0.1 $\mathrm{ml}$ of $0.001 \mathrm{M}$ sodium pyruvate was added, and the decrease in absorption at $340 \mathrm{~m} \mu$ was measured in the Beckman DU spectrophotometer. Readings were obtained every 15 or 30 seconds for several minutes in order to insure linearity of decrease in optical density with time. One unit of dehydrogenase activity was defined as a decrease in optical density at $340 \mathrm{~m} \mu$ of 0.001 per minute per $\mathrm{ml}$ of eluate.

Vertical starch gel electrophoresis of the sonicated portions of heart, kidney, liver, lung, skeletal muscle, and skin was performed according to the method of Smithies (16). Gels were prepared from commercially available starch (starch-hydrolysed, Connaught Medical Research Laboratories, Toronto, Canada) in phosphate-citric acid buffer, $0.01 \mathrm{M}, \mathrm{pH} 7.0$. Approximately $0.05 \mathrm{ml}$ of the supernatant fluid from the sonicated portion was applied to each slit at the origin. Molarity of the phosphate-citric acid buffer in the proximal and distal vessels was 0.2. A potential gradient of $6 \mathrm{v}$ per $\mathrm{cm}$ was employed for 12 hours at $22^{\circ} \mathrm{C}$. After electrophoresis the tray was refrigerated, then sliced into two sections which were stained for $\mathrm{LDH}$ activity with nitro blue tetrazolium (BT) (Nutritional Biochemicals) as dye and phenazine methosulfate (Aldrich Chemical Co.) as electron transporter (17). The nitro BT, relatively insoluble in water, was readily dissolved in diethylene glycol. The incubating medium for the gel consisted of DL-lactic acid, $0.05 \mathrm{M}$ adjusted to $\mathrm{pH} 7.0,12.0 \mathrm{ml} ; \mathrm{DPN}, 10 \mathrm{mg}$ per $\mathrm{ml}$ adjusted to $\mathrm{pH} 8.0$, $2.4 \mathrm{ml}$; nitro BT, $1 \mathrm{mg}$ per $\mathrm{ml}, 6.4 \mathrm{ml}$; Tris buffer, $\mathrm{pH}$ $8.3,0.1 \mathrm{M}, 62.0 \mathrm{ml}$; and phenazine methosulfate, $1.6 \mathrm{mg}$ per $\mathrm{ml}, 7.2 \mathrm{ml}$. The gel was overlaid with this solution and incubated at $37^{\circ} \mathrm{C}$ in the dark for approximately one hour. Controls, consisting of incubating the gel in solutions without substrate and of incubating the gel in solutions without coenzyme, have been described (18).

Density gradient ultracentrifugation was performed according to a method described by Kunkel (19). Individual isozymes were isolated from sonicated portions of human liver (isozymes 5 and 4) and human erythrocytes (isozymes 1-3) by starch block electrophoresis. Each isozyme was obtained by pooling appropriate eluates from the starch block, and was concentrated either on carbowax (20) or by low pressure ultrafiltration (21). A gradient ranging from 10 to 40 per cent sucrose was prepared in a volume of $4.8 \mathrm{ml}$, and 0.1 or $0.2 \mathrm{ml}$ of the concentrated isozyme was added as a top layer. A swinging bucket rotor was employed in the Spinco preparative ultracentrifuge, and centrifugation at $35,000 \mathrm{rpm}$ was performed for 18 hours at $0^{\circ} \mathrm{C}$. The bottoms of the tubes were then punctured by needle; samples of 5 drops each were collected in separate tubes; in some experiments samples of 10 drops each were collected. These samples were then assayed for $\mathrm{LDH}$ activity. As a reference for purposes of comparing the sedimentation behavior of the isolated isozymes, an immunologically pure $7 \mathrm{~S}$ gamma globulin was run alone in an identical density gradient and also in a tube containing $\mathrm{LDH}$ isozyme 5 .

\section{RESULTS}

Localization by histochemical techniques of the $\mathrm{LDH}$ isozymes in various human tissues is shown in Figures 1 and 2. Each of the six human tissues separated electrophoretically has in common five $\mathrm{LDH}$ isozymes (Figure 1). The distribution of the total LDH activity among these bands, however, varies in different tissues. The heart and the kidney exhibit most activity in the anodal bands. 
VESELL, OSTERLAND, BEARN, AND KUNKEL

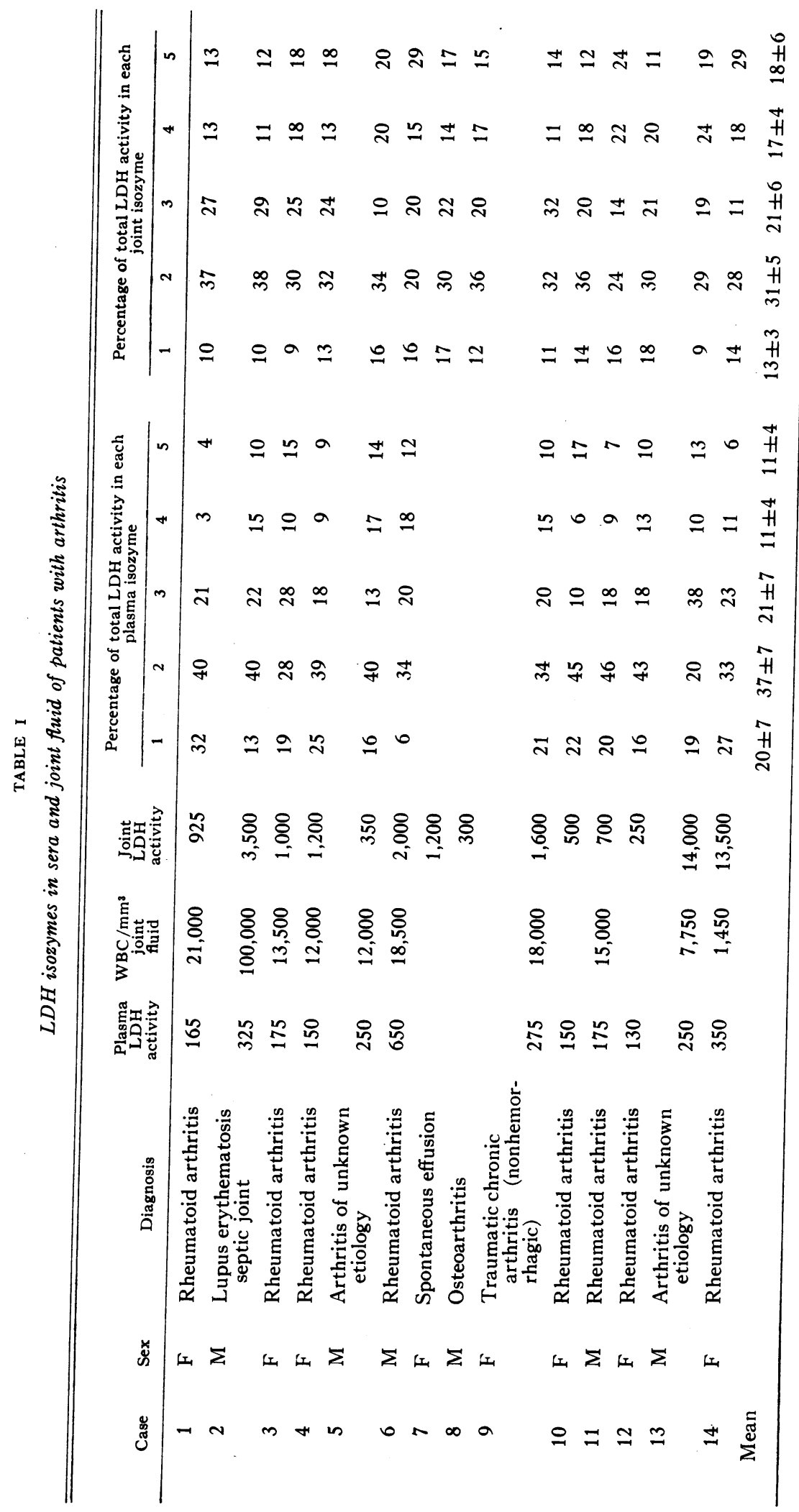




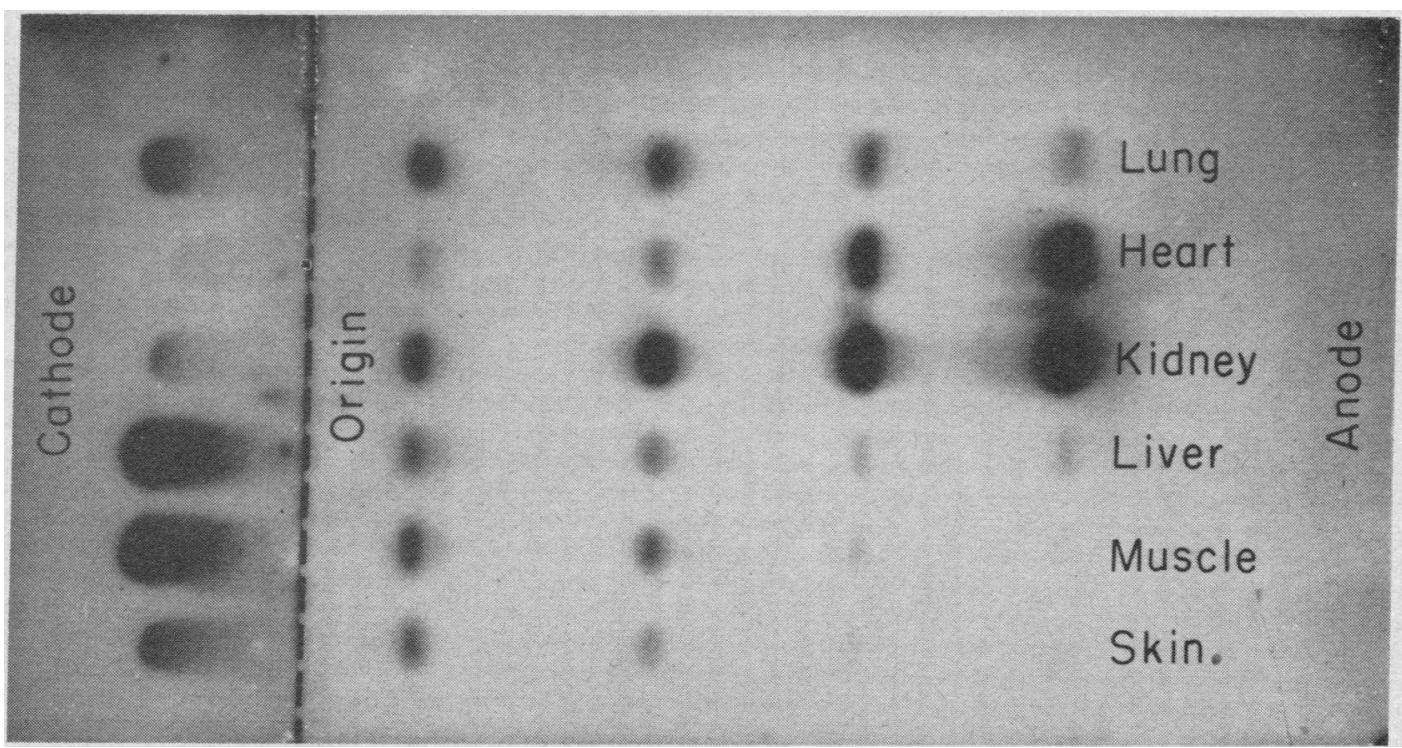

Fig. 1. Starch Gel stained for LDH Activity. The total LDH activity of the human tissues applied was lung $14,000 \mathrm{U}$ per $\mathrm{ml}$, heart $34,000 \mathrm{U}$ per ml, kidney $34,000 \mathrm{U}$ per ml, liver $34,000 \mathrm{U}$ per ml, skeletal muscle $34,000 \mathrm{U}$ per $\mathrm{ml}$, and skin 7,000 $\mathrm{U}$ per $\mathrm{ml}$. The multiple cathodal bands in the liver homogenate are not clearly seen in the photograph, al though they are easily seen on the gel.

whereas the majority of the total $\mathrm{LDH}$ activity of liver, skeletal muscle, and skin occurs in the cathodal bands. Human white cells have most of their LDH activity in isozymes 3,4 , and 5 , whereas erthrocytes contain the majority of their LDH activity in isozymes 1 and 2 and do not contain isozyme 5 (Figure 2). The liver revealed several bands of $\mathrm{LDH}$ activity in the cathodal region. Sonicated portions of livers from five other individuals also revealed a multiplicity of bands in the cathodal region. To determine whether these bands were produced by polymers, ultracentrifugation in a sucrose density gradient was performed on a concentrate of all the LDH activity in the cathodal region of a starch block on which $30 \mathrm{ml}$ of human liver homogenate had been separated. After density gradient ultracentrifugation most of the LDH activity was found in a single tube (Table II). The anodal migrating isozymes also exhibited most of their LDH activity in an identical position when subjected to density gradient ultracentrifugation. Since under similar conditions $7 \mathrm{~S}$ gamma globulin settles in this same region (Table II), each of the LDH isozymes may be assumed to have a sedimentation rate of approximately $7 \mathrm{~S}$. Polymers of $7 \mathrm{~S}$ gamma globulin have been distinguished from $7 \mathrm{~S}$ gamma globulin on the basis of sedimentation behavior under identical conditions (19). Therefore, by this technique the multiple cathodal bands of LDH activity obtained from liver homogenates cannot be identified as polymers.

Distribution of total LDH activity among the five isozymes in synovial fluid and sera from patients with rheumatoid arthritis and arthritis of other etiologies is shown in Table I. In most cases

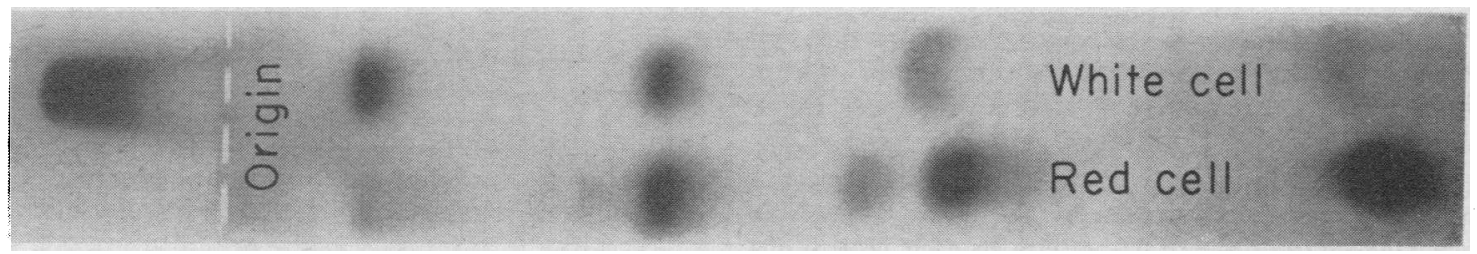

Fig. 2. Starch Gel STAINed FOR LDH ACtivity. 25,000 U per $\mathrm{ml}$ of leukocyte extract and hemolysate was applied. Note in human erythrocytes the splitting of isozyme 2 and the absence of isozyme 5 . The splitting of erythrocyte isozyme 2 has been described previously (18). 
TABLE II

Density gradient zone ultracentrifugation of LDH isozymes isolated from a starch block *

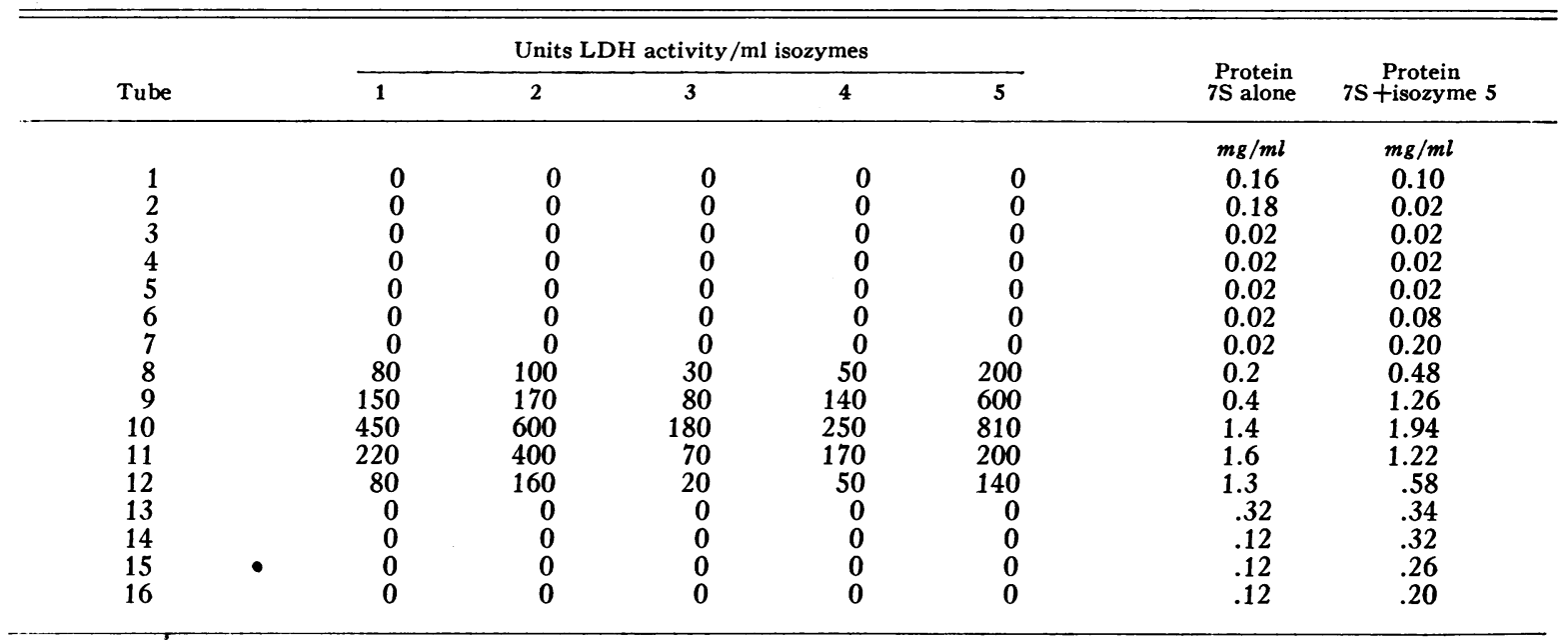

* A sucrose gradient of 10 to 40 per cent was prepared in a final volume of $5.0 \mathrm{cc}$ (19).

plasma isozyme 5 is elevated above 0 to 3 per cent, which we observed in normal controls to be the value of isozyme 5 (Figure 3 ); this agrees with the normal values for isozyme 5 reported by other

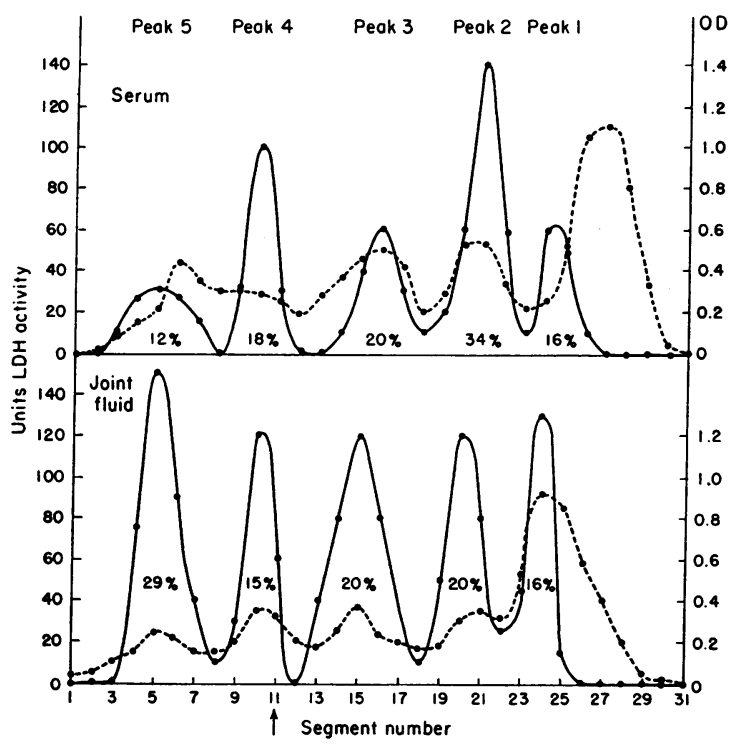

Fig. 3. Distribution of LDH Activity in SERUM AND JOINT FLUID SEPARATED SIMULTANEOUSLY ON A STARCH BLOCK FROM A PATIENT WITH RHEUMATOID ARTHRITIS. The enzyme activity is indicated by the solid line; the protein concentration by the dotted line. The percentage of the total LDH activity in each peak is indicated within the peak. Note the high value of isozyme 5 in the joint fluid and its elevation above normal values ( 3 per cent or less) in the serum. authors $(4,22)$. The mean value for serum isozyme 5 in the 12 arthritic patients in whom it was determined was $10.6 \pm 3.8$ per cent. Isozyme 5 of joint fluid also contains a high proportion of the total LDH activity, $17.9 \pm 5.9$ per cent. The mean values for isozymes 1,2 , and 3 in arthritic sera were $20 \pm 7$ per cent, $37 \pm 7$ per cent, and $21 \pm 7$ per cent, respectively, and are either in the same range or slightly lower than the values previously reported for these isozymes in normal human sera : 31 to 37 per cent for isozyme 1,43 to 55 per cent for isozyme 2 , and 12 to 23 per cent for isozyme 3 (3). Since the joint fluid is in equilibrium with the blood of which it is an ultrafiltrate, assays of the total LDH activity of the joint fluid and the serum were performed to determine if a gradient of activity existed. Table I indicates that the joint fluid contained an appreciably higher LDH activity than an equal volume of the patient's serum, although in the seven arthritic patients in whom it was measured, the joint fluid protein value was much lower than that for serum and ranged between 700 to $1,300 \mathrm{mg}$ per cent. The total LDH activity of the joint fluid varied from 1.4 to 56 times the total LDH activity of the serum, and therefore the elevation of $\mathrm{LDH}$ activity in the joint fluid appears not to be derived from the serum. The normal serum LDH activity with standard deviation in our laboratory is $284 \pm 130$ $\mathrm{U}$, and only 2 arthritic sera of 12 are significantly elevated. The white cell count of the synovial 


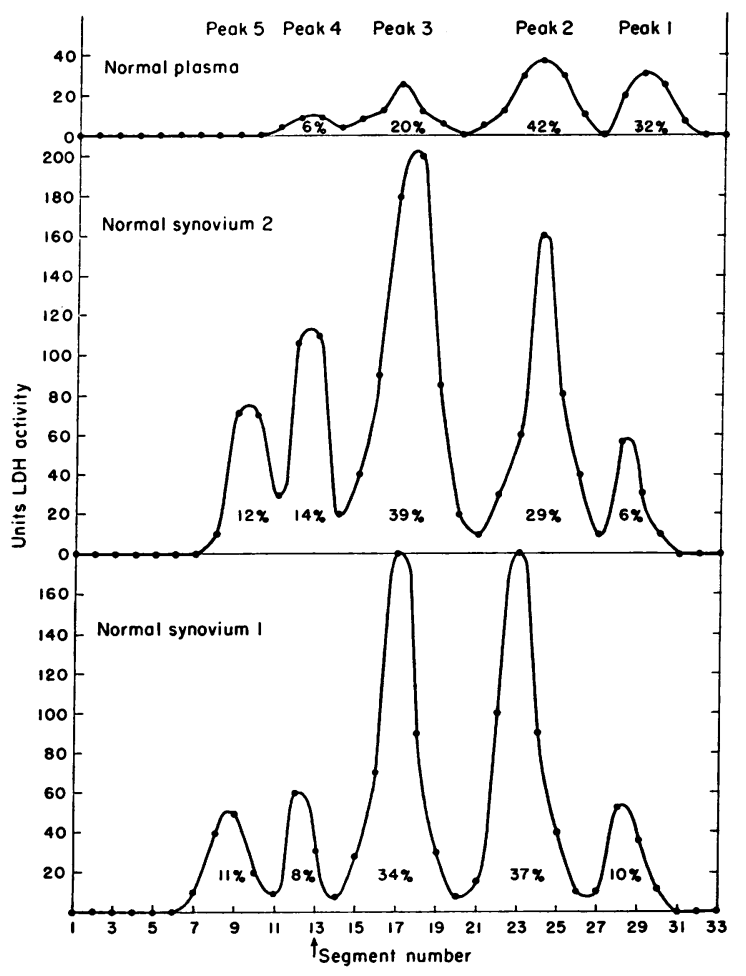

Fig. 4. Distribution of LDH ACtivity IN TWO NORMAL SYNOVIA SEPARATED BY STARCH BLOCK ELECTROPHORESIS SIMUltaNeOUSLY WITH NORMAL PLASMa.

fluid was elevated in all but one instance (Table I). Although the high percentage of isozyme 5 in the joint fluid is consistent with the hypothesis that the white cell may be its source, the elevation of $\mathrm{LDH}$ activity in synovial fluid is not proportional to the number of white cells observed (Table I). Normal human synovium obtained at autopsy and separated electrophoretically also reveals an isozyme pattern resembling that of synovial fluid (Figure 4 and Table I).

\section{DISCUSSION}

Serum isozyme 5 is elevated in hepatitis $(4,7)$, and the data presented in this paper indicate that it is also increased in the sera of some arthritic patients with joint effusions. The normal values of isozyme 5 are between 0 and 3 per cent, and the values in 12 sera from arthritic patients with joint effusions of $10.6 \pm 3.8$ per cent are significantly elevated. Therefore, isozyme 5, if employed to localize pathology, could prove to be misleading. Although serum isozymes have been useful as an adjunct in diagnosis of certain condi- tions $(3-10,22)$, it is probably an oversimplification to expect, as some have (10), that specific localization of pathology to any organ can be inferred by an analysis of serum for LDH isozymes. Figures 1 and 2 illustrate the similarity among tissues in the number and the electrophoretic mobility of $\mathrm{LDH}$ isozymes and show that the main differences are in distribution of total LDH activity among the five isozymes. Previously isozyme 5 was not observed in heart and kidney $(7,12,23)$, but with refined methods has been identified in trace amounts in the present report.

The elevation of total LDH activity in the synovial fluid and sera of certain patients with arthritis may be due to LDH release from leukocytes, or from the synovial membrane, or from both, as suggested by the resemblance of the isozyme pattern in normal leukocytes and in synovium to that of pathologic synovial fluids. Both glycolytic and oxidative metabolic pathways of synovium are elevated in acute arthritis (24). Several enzymes, including amylase (25), lipase (25), a protease (26), peroxidase (26), alkaline phosphatase (27), and aminotripeptidase (28), have been identified in human synovial fluid, and variations of $\beta$-glucuronidase activity in synovial fluid from patients with degenerative joint disease or a traumatic joint effusion have been described (29). The source of this elevation of $\beta$-glucuronidase activity was not completely clarified, although it was stated that intact leukocytes, disintegrated leukocytes, and synovial membrane structures contribute enzyme activity to the synovial fluid (29).

Although the isozyme pattern of human leukocytes has been described previously (7), isozyme 5 was not observed. This may be explained either by postulating greater efficiency in yield of enzyme from the presently employed technique of sonic disruption or by attributing loss of activity of isozymes 5 and 4 , known to be more heat labile than the faster migrating forms (22), to the repeated freezing and thawing previously used to lyse leukocytes. The fact that isozyme 5 is more heat labile than the other isozymes renders its clinical use somewhat hazardous, since failure to observe isozyme 5 may be attributable to its inactivation by heat during electrophoresis (22). The present study demonstrates that under the conditions employed elevations of isozyme 5 may be detected in pathologic sera. Isozyme 5 on 
starch gels behaves differently from the anodally migrating isozymes in another respect: the activity of isozyme 5 declines more rapidly on serial dilutions than does that of the other isozymes. Furthermore, the electrophoretic mobility of isozyme 5 decreases with increasing dilution (23) (Figure 1). This effect is not observed on the starch block. Therefore, it may be advisable when isozymes are studied for diagnostic purposes to avoid the use of the starch gel particularly when the material to be assayed contains low total $\mathrm{LDH}$ activity (23).

In addition to their specific application in clinical medicine isozymes have been utilized in other biological contexts. Allen has elucidated the genetic control of the esterase isozymes of Tetrahymena pyriformis by crossing different strains and has shown that several esterase isozymes are determined by alleles at a single locus (30). Markert and Møller first demonstrated that certain fetal tissues exhibited differences in their $\mathrm{LDH}$ isozyme pattern from that of the adult (6), and Kaplan and Ciotti showed that fetal rat heart $\mathrm{LDH}$ could be distinguished from adult rat heart LDH by use of DPN analogs (31). These studies were extended, and during development of chick muscle and liver, sequential changes characterized by a gradual increase in the concentration of cathodal bands (32) were observed. In tissue culture of various chick fetal tissues, similar sequential changes occurred (32). Appella and Markert dissociated a purified $\mathrm{LDH}$ isozyme of beef heart into four subunits by treatment with $12 \mathrm{M}$ urea or $5 \mathrm{M}$ guanidine hydrochloride (33). The molecular weight of the isolated LDH isozyme from beef heart was 135,000 and that of each of the four subunits observed in the ultracentrifuge after dissociation was 34,000 (33). These subunits could be separated into at least two classes on the basis of charge (33). By assorting these two subunits into various combinations of four, the five isozymes observed in several vertebrate species may be constructed (33).

\section{SUMMARY}

1. Synovial fluid from 12 patients with various types of arthritis contained 1.4 to 56 times the LDH activity of an equal volume of their serum. Total serum LDH activity was not usually elevated in these patients, but their serum isozymes were generally altered and revealed a significantly higher percentage of isozyme $5(10.6 \pm 3.8$ per cent) than did normal serum ( 0 to 3 per cent). Joint fluids contained high activities of isozyme 5. Since the isozyme patterns of leukocytes and of synovial tissue both resemble that of joint fluid, the elevated LDH activity of joint fluid may have its source either in the white cell, or the synovial membrane, or both.

2. Localization on starch gels of the LDH isozymes from homogenates of various human tissues showed that each tissue possessed four anodal isozymes and at least one cathodal isozyme. Differences among tissues consisted primarily in the distribution of the total LDH activity among isozymes. Liver, skeletal muscle, skin, and leukocytes exhibited most activity in the cathodal bands, whereas most of the LDH activity of heart, kidney, and erythrocytes was concentrated in the two most rapidly migrating anodal bands. Lung $\mathrm{LDH}$ activity was equally divided among the five isozymes. The only cell studied lacking isozyme 5 was the mature erythrocyte. The five human isozymes were isolated and found to behave identically when subjected to ultracentrifugation in a sucrose density gradient.

3. Since most human tissues contain the same number of $\mathrm{LDH}$ isozymes and differ only in distribution of total activity among them, localization of pathology to a single organ solely by analysis of serum LDH isozymes may prove misleading. Isozyme 5, previously regarded as an index of liver damage, is also elevated in arthritic synovial fluid and sera.

\section{ACKNOWLEDGMENT}

The authors wish to acknowledge the help of Dr. Ade T. Millhorat of the Institute for Muscle Disease for making available clinical material.

\section{REFERENCES}

1. Meister, A. Reduction of $\alpha, \gamma$-diketo and $\alpha$-keto acids catalyzed by muscle preparations and by crystalline lactic dehydrogenase. J. biol. Chem. 1950, 184, 117.

2. Neilands, J. B. Studies on lactic dehydrogenase of heart. I. Purity, kinetics, and equilibria. J. biol. Chem. 1952, 199, 373.

3. Vesell, E. S., and Bearn, A. G. Localization of lactic acid dehydrogenase activity in serum fractions. Proc. Soc. exp. Biol. (N. Y.). 1957, 94, 96. 
4. Wieme, R. J. Studies on Agar Gel Electrophoresis. Brussels, Arscia, 1959.

5. Vesell, E. S., and Bearn, A. G. Observations on the heterogeneity of malic and lactic dehydrogenase in human serum and red blood cells. J. clin. Invest. 1958, 37, 672 .

6. Markert, C. L., and Møller, F. Multiple forms of enzymes: tissue, ontogenetic, and species specific patterns. Proc. nat. Acad. Sci. (Wash.) 1959, 45, 753.

7. Vesell, E. S., and Bearn, A. G. Isozymes of lactic dehydrogenase in human tissues. J. clin. Invest. 1961, 40, 586.

8. Sayre, F. W., and Hill, B. R. Fractionation of serum lactic dehydrogenase by salt concentration gradient elution and paper electrophoresis. Proc. Soc. exp. Biol. (N. Y.) 1957, 96, 695.

9. Hess, B. DPN-dependent enzymes in serum. Ann. N. Y. Acad. Sci. 1958, 75, 292.

10. Plagemann, P. G. W., Gregory, K. F., and Wróblewski, F. The electrophoretically distinct forms of mammalian lactic dehydrogenase. I. Distribution of lactic dehydrogenases in rabbit and human tissues. J. biol. Chem. 1960, 235, 2282.

11. Wieme, R. J., and Van Maercke, Y. The fifth (electrophoretically slowest) serum lactic dehydrogenase as an index of liver injury. Ann. N. Y. Acad. Sci. 1961, 94, 898.

12. Wieland, Th., and Pfleiderer, G. Nachweis der Heterogenität von Milchsäure-dehydrogenasen verschiedenen Ursprungs durch Trägerelektrophorese. Biochem. Z. 1957, 329, 112.

13. Hess, B., and Walter, S. I. Chromatographic differentiation of lactate dehydrogenase of human tissue and serum. Ann. N. Y. Acad. Sci. 1961, 94, 890.

14. Kunkel, H. G. Zone electrophoresis. Meth. biochem. Anal. 1954, 1, 141.

15. Kubowitz, F., and Ott, P. Isolierung und Kristallisation eines Gärungsfermentes aus Tumoren. Biochem. Z. 1943, 314, 94.

16. Smithies, O. An improved procedure for starchgel electrophoresis: further variations in the serum proteins of normal individuals. Biochem. J. 1959, 71, 585.

17. Vesell, E. S. Significance of the heterogeneity of lactic dehydrogenase activity in human tissues. Ann. N. Y. Acad. Sci. 1961, 94, 877.

18. Vesell, E. S., and Bearn, A. G. Variations in the lactic dehydrogenase of vertebrate erythrocytes. J. gen. Physiol. 1962, 45, 553.

19. Kunkel, H. G. Macroglobulins and high molecular weight antibodies in The Plasma Proteins, F. W.
Putnam, Ed. New York, Academic Press, 1960, vol. 1, p. 279.

20. Kohn, J. A simple method for the concentration of fluids containing protein. Nature (Lond.) 1959, 183, 1055.

21. Berggard, I. Proteins, glycoproteins and mucopolysaccharides in normal human urine. I. Fractionation of non-dialyzable materials for ultrafiltration and by zone electrophoresis. Arkiv för Kemi. 1961, 18, 291.

22. Wróblewski, F., and Gregory, K. F. Lactic dehydrogenase isozymes and their distribution in normal tissues and plasma and in disease states. Ann. N. Y. Acad. Sci. 1961, 94, 912.

23. Vesell, E. S. Effect of dilution on the lactic dehydrogenase isozyme pattern obtained in the starch gel. Nature (Lond.) 1962, 195, 497.

24. Dingle, J. T. M., and Thomas, D. P. P. In vitro studies on human synovial membrane. A metabolic comparison of normal and rheumatoid tissue. Brit. J. exp. Path. 1956, 37, 318.

25. Podkaminsky, N.-A. Rôle des ferments du liquide synovial. C. R. Soc. Biol. (Paris) 1931, 106, 915.

26. Ropes, M. W., and Bauer, W. Synovial Fluid Changes in Joint Disease. Cambridge, Mass., Harvard University Press, 1953, p. 9.

27. Ropes, M. W., Bennett, G. A., and Bauer, W. The origin and nature of normal synovial fluid. $J$. clin. Invest. 1939, 18, 351.

28. Ziff, M., Scull, E., Ford, D., McEwen, C., and Bunim, J. J. Effects of intra-articular hydrocortisone acetate on the clinical course, aminotripeptidase activity and other changes in the synovial fluid in rheumatoid arthritis. Ann. rheum. Dis. 1952, 11, 301.

29. Jacox, R. F., and Feldmahn, A. Variations of beta glucuronidase concentration in abnormal human synovial fluids. J. clin. Invest. 1955, 34, 263.

30. Allen, S. L. Genetic control of the esterases in the protozoan Tetrahymena pyriformis. Ann. N. Y. Acad. Sci. 1961, 94, 753.

31. Kaplan, N. O., and Ciotti, M. M. Heterogeneity of the lactic dehydrogenases of newborn and adult rat heart as determined with coenzyme analogs. Biochim. biophys. Acta (Amst.) 1961, 49, 425.

32. Philip, J., and Vesell, E. S. Sequential alterations of lactic dehydrogenase isozymes during embryonic development and in tissue culture. Proc. Soc. exp. Biol. (N. Y.) 1962, 110, 582.

33. Appella, E., and Markert, C. L. Dissociation of lactic dehydrogenase into subunits with guanidine hydrochloride. Biochem. biophys. Res. Commun. $1961,6,171$. 